\title{
The history of the 125 year old Eötvös torsion balance
}

\author{
Zoltán Szabó ${ }^{1}$
}

Received: 17 March 2015/Accepted: 19 June 2015/Published online: 24 July 2015

(C) Akadémiai Kiadó 2015

\begin{abstract}
The paper is a comprehensive history of Eötvös' torsion balance from the initial experiments of its inventor to the final stages of torsion balance development. It gives a review of the characteristics of the successive types of the instrument and the main features of their development. It covers briefly the contribution of Ferdinand Süss the constructor of the instruments whose mechanical expertise contributed to the success of the torsion balances to a great extent. It appreciates the activity of Hugo Böckh, a well-known Hungarian geologist, who recognised the geological aspects of torsion balance surveys in an early period and initiated their introduction to oil prospecting.
\end{abstract}

Keywords Eötvös · Torsion balance $\cdot$ Gradient $\cdot$ Curvature $\cdot$ Askania

\section{The beginnings}

Loránd Eötvös' interest in gravity dates back to 1886 when he began his first experiments using the Coulomb/Cavendish balance. He improved the balance by "ageing" the torsion wire, thereby eliminating the inherent tensions introduced by the manufacturing process. This made the instrument capable of high precision measurements.

His first gravity instrument was built in 1887 to demonstrate the effect of gravitational attraction. It was the classic Coulomb balance, comprising a horizontal beam with two identical masses at each end, suspended on a torsion wire. The balance was fixed to a wall and a small table was placed under it in such a way that two lead weights could be moved on to either side of the balance. If the lead weights were moved from one side to the other,

Zoltán Szabó

szabo.zoltan@mfgi.hu

1 Geological and Geophysical Institute of Hungary (MFGI), Columbus u. 17-23, Budapest 1145, Hungary 
while synchronized with the movement of the balance, the attraction of the weights would continually increase its amplitude-like a swing being pushed. Later on, the transposition of the lead weights was automatized and the movement of the balance was photographically recorded. The instrument was called a Gravitational Multiplicator (Fig. 1).

In the course of his experiments with the Coulomb balance, Eötvös set up the equation for a case when there is no extra mass in the vicinity of the balance. As can be seen from Fig. 2a, if the equipotential surface deviates from a sphere, there are small horizontal forces turning the beam into the direction of the smallest curvature, namely this balance can measure the degree of deviation of the equipotential surface from the spherical shape. From the equation it also became clear that if one of the masses is lowered, the force acting on the lower mass can be resolved into a vertical and a horizontal component (Fig. 2b). The latter component exercises torque against the resistance of the torsion wire resulting in

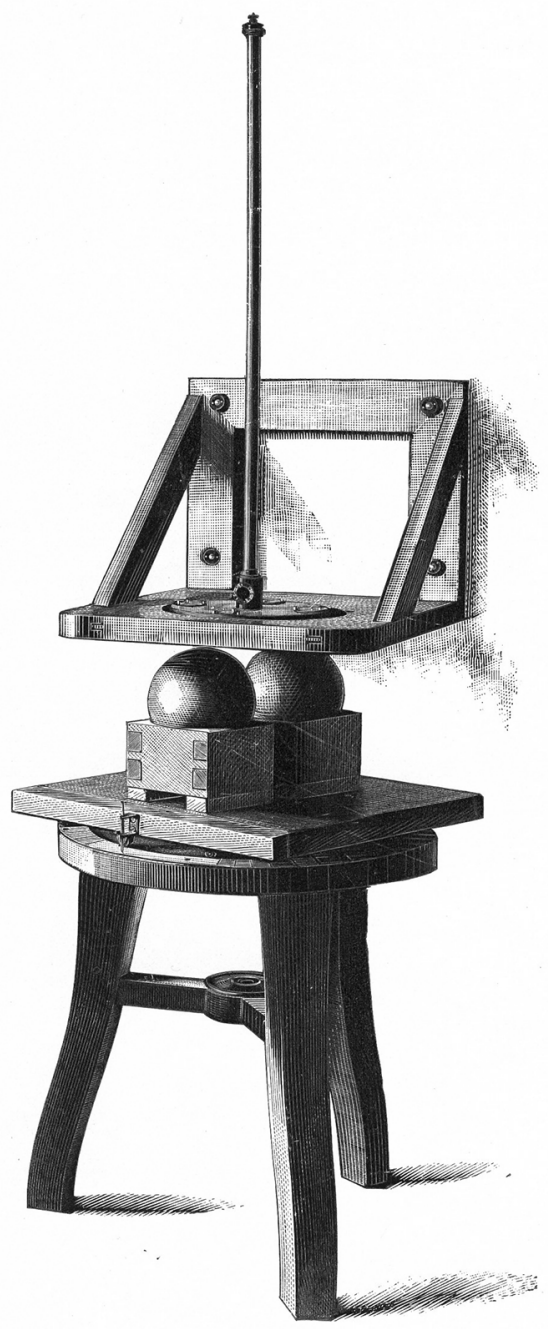

Fig. 1 Gravitational Multiplicator, 1887 

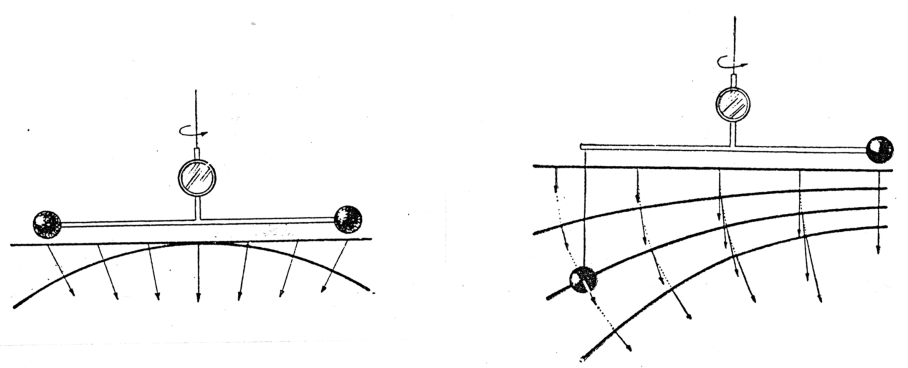

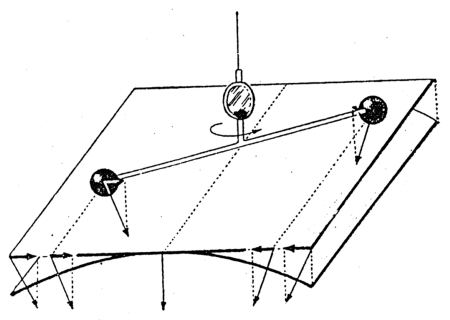

(a)

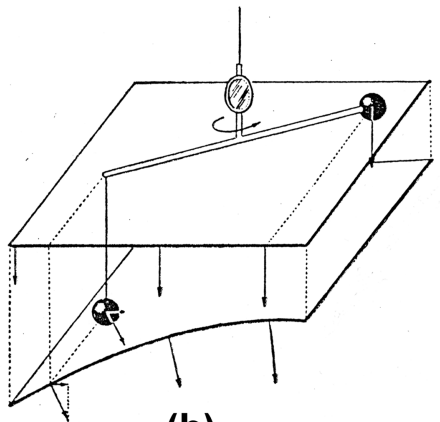

(b)

Fig. 2 The effect of the shape of the equipotential surface on the Coulomb balance (Curvature Variometer) (a), and the effect of gravity on the Horizontal Variometer, the so-called Eötvös Torsion Balance (b)

the turning of the beam in the direction of the increase of gravity. Accordingly, it is measuring the horizontal gradient of gravity as well (Egyed 1969).

Based on his theoretical findings, Eötvös built two instruments in 1890-1891: the Curvature Variometer (Fig. 3a) and the Horizontal Variometer (Fig. 3b), now known as the Eötvös torsion balance. The instruments were constructed for laboratory use, observation was carried out with the help of a mirror fixed to the stem of the beam, and a separate scale and telescope.

Eötvös describes his instrument as follows: "The means I use is a simple, straight stick with masses attached to each end and encased in metal, so that it will not be disturbed by the movement of air or differences in temperature. All mass near or far has an attracting influence on the stick, but the wire, from which it hangs, resists this effect and twists in the opposite direction thereby producing by its twisting the exact measurements of the forces imposed upon it. This is nothing but an adapted version of the Coulomb balance. It is as simple as Hamlet's flute, if you know how to play it. Just as the musician can coax entrancing melodies from his instrument, so the physicist, with equal delight, can measure the finest variation in gravity. In this way we can examine the Earth's crust at depths that the eye cannot penetrate and the drilling rig cannot reach."

In fact the instrument is very simple, but due to its exceptional precision it is a complex and highly refined device, the only one geophysical instrument, unsurpassable from its birth to our age. To characterize its high sensitivity, the following example can be mentioned: "If a piece of wire weighing 1 gram were stretched out to encircle the Earth around 

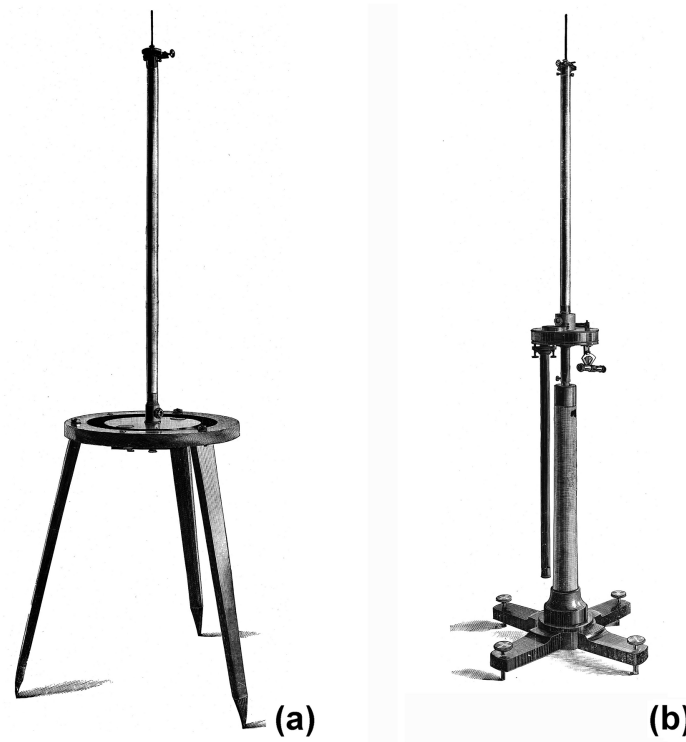

Fig. 3 Curvature Variometer (a), and Horizontal Variometer, the first and Eötvös torsion balance, 1891 (b)

its equator 25 times and $1 \mathrm{~cm}$ of the stretched wire were cut, the segment would weigh $1 \times 10^{-12} \mathrm{~g}$. This weight is in the order of the magnitude of the forces measured by the Eötvös torsion balances" (Pekár 1941).

\section{The 'heroic' or platinum age}

The first 'age' in the history of the torsion balance, which covers Eötvös' lifetime, can be called the 'platinum age' on account of high density platinum used for the masses of the balance as this allowed the smallest possible dimensions. Serial production of balances with gold masses started only after Eötvös' death.

Following experiments in the laboratory Eötvös made observations in a canvas tent, set up in his own garden. Daytime temperature changes caused wide variations in the results but the more stable night-time temperatures gave much more reliable results. From then on until 1932 all field observations were carried out during night-time.

The first field observations were carried out in August 1891 on Ság Hill near Celldömölk (Transdanubia, W. Hungary). The then still truncated cone-shaped hill made it easy to calculate its gravitational effect and so it was suitable for checking the observational results. Previously Colonel Robert von Sterneck, later head of Astrogeodetical Department of the $K$. u. K. Militär-geografisches Institut (Vienna), had carried out observations with his relative pendulum apparatus at the top of the hill between two points $150 \mathrm{~m}$ apart and found a difference of $33 \mathrm{mGal}$ which is roughly equivalent in gradient to 2200 Eötvös units. Observations carried out by Eötvös—in which he was assisted by Radó Kövesligheti, Károly Tangl and Lajos Bodola, later all well-known university professors (Fig. 4)—disproved von Sterneck's results, proving that there was nothing 'anomalous' about Ság Hill.

With reference to the Eötvös balance, mention must be made of Ferdinand Süss (Fig. 5) who was born into a dynasty of engineers in Marburg, Germany in 1848. At the invitation 


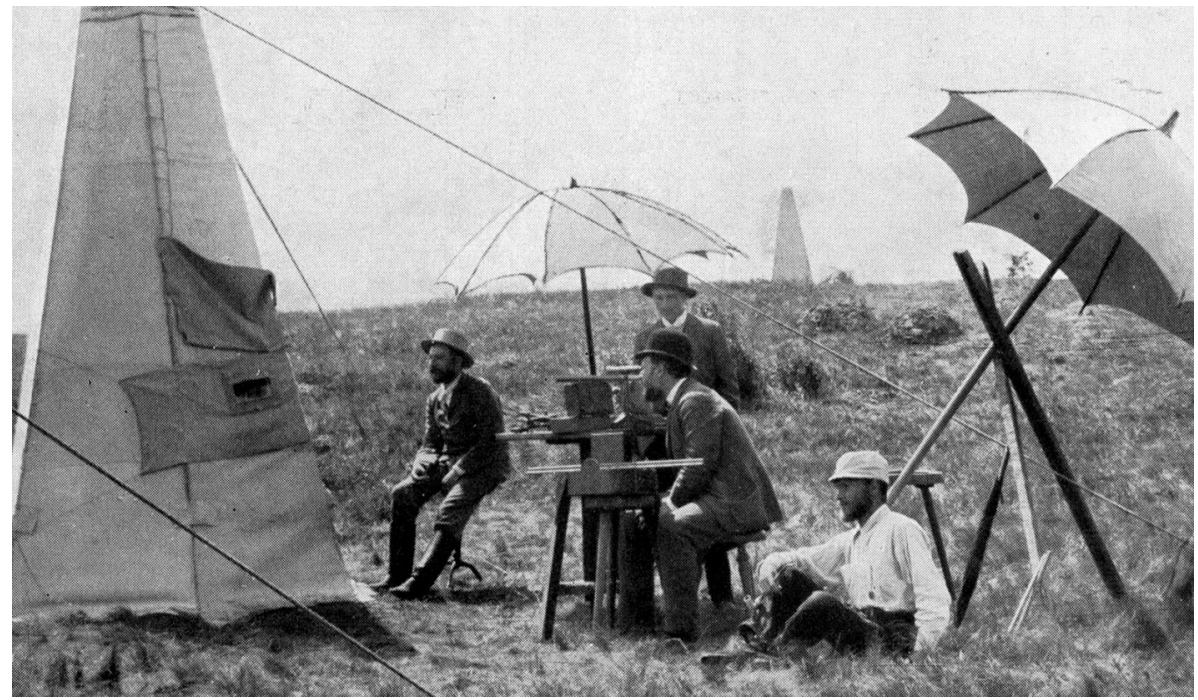

Fig. 4 The famous Ság-hill survey, 1891
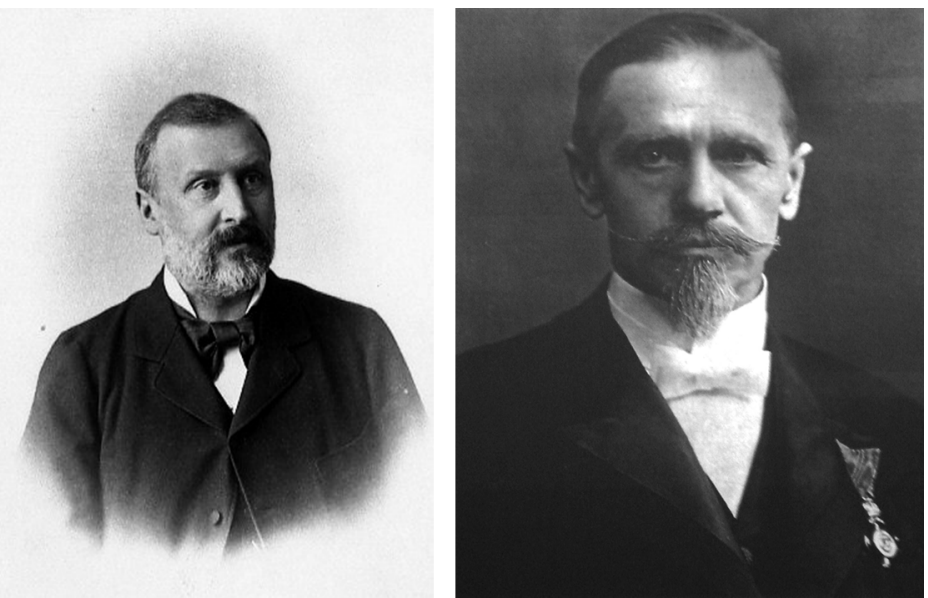

Fig. 5 The creators: Loránd Eötvös ${ }^{1}$ (1848-1919) the scientist (left) and Ferdinand Süss (1848-1921) his partner in realizing his ideas (right)

of the University of Kolozsvár (now Cluj in Romania) he was invited to settle in Hungary. In 1884 the Minister for Education and Religious Affairs transferred him to Budapest and charged him to set up an engineering training workshop. Initially his workshop carried out all sort of engineering jobs but he soon specialized in precision mechanical engineering. His output included geodetic, mining, marine, astronomical and other instruments used in various scientific fields. The government's subsidies for the workshop ceased in 1900 and Ferdinand Süss took over the workshop as his own private company. He proved to be a less

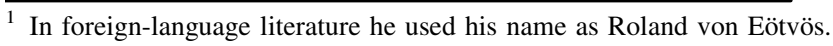


successful businessman than engineer as in spite of the large demand for his products he was constantly beset with financial problems. For this reason in 1918 he turned his company into a joint stock enterprise under the name of Ferdinand Süss Mechanical and Optical Institute and concerned himself with technical matters only. He was the founding father of the Hungarian instrument making industry and nurtured a new generation of engineers who became well-known and successful experts in their fields. Süss' instruments gained many awards and the company became well known internationally.

Eötvös started his association with Süss when he was designing his first balance and Süss became his collaborator in the mechanical design and manufacture of the instruments. In his major publication on gravity and magnetic exploration (Eötvös 1896), this is what he says about Süss's activities: “All the instruments which I needed for my work were made here in Budapest by Mr Ferdinand Süss, the director of the State Mechanical Training Workshop with that outstanding care, accuracy and skill that characterizes his handiwork" Süss can be thanked for the unique quality of his creations both from a mechanical and aesthetic point of view.

After the successful Ság Hill survey, Eötvös spent the rest of his life perfecting his torsion balance. To achieve his goal of studying in detail the equipotential surface of the gravitational field, he needed an instrument that was just as easy to use in the field as in the laboratory. This is how the Simple Gravity Variometer was born in 1898 which was later renamed the Balaton balance (Fig. 6). This instrument had a built-in optical readout making observations much simpler. At the 1900 World Expo in Paris the instrument was

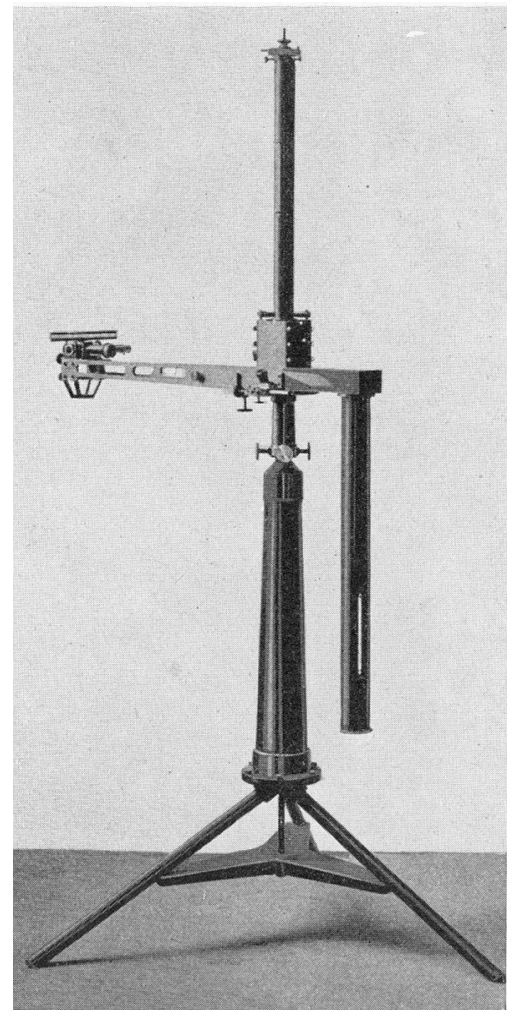

Fig. 6 Balaton balance, the first torsion balance constructed for field work, 1898 


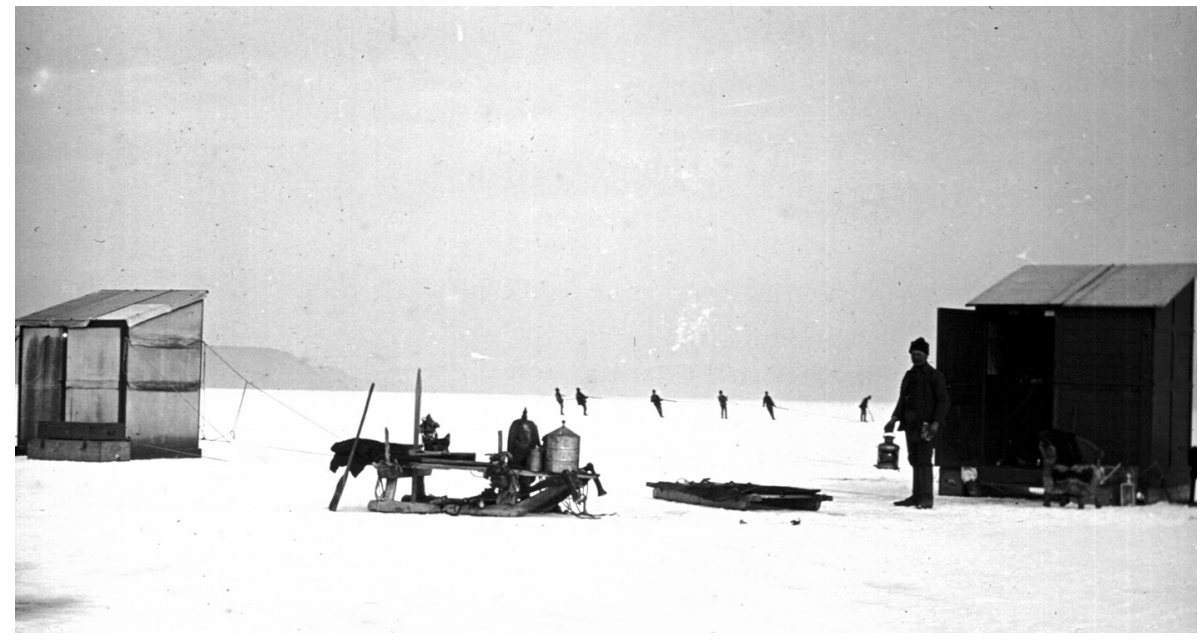

Fig. 7 Expedition on frozen Lake Balaton, 1901

awarded the Grand Prix. It was with this instrument that Eötvös and his collaborators carried out the first significant survey during the winters of 1901 and 1903 on the frozen surface of Lake Balaton (Fig. 7). The locality was chosen to avoid the effect of topography which, although calculable to the required accuracy, was a very labour-intensive task in those pre-computer days. The smooth frozen surface made this unnecessary, as only the gravitational effect of the Tihany peninsula had to be taken into account (Eötvös 1908).

Nineteen-hundred-and-two saw the birth of the Large double balance housing two beams in antiparallel position (Fig. 8a). This arrangement allowed a significant reduction in the number of observations needed at any one station. While an instrument with a single balance needed observations in five different azimuths the double balance only needed three. To the original five unknowns a sixths was added, the second beam's equilibrium; however, by observing in three azimuths for each balance, three equations could now be set up. It was also possible to reduce the observational period from $1 \mathrm{~h} 40 \mathrm{~min}$ to $1 \mathrm{~h}$ (Fröhlich 1930; Pekár 1941).

For transporting this fairly large and heavy instrument in the field, a special observation cart was designed in which the instrument was carried in an unassembled but vertical state (Fig. 8b). The instrument had to be assembled and disassembled at each station. Partly due to this and the 60 min observational period only one observation could be made each night. As the observer had to be present during observation, spending his night in a nearby tent, he was obliged to move daily. The cart was pulled by horses or oxen. For longer distances the instrument carts were transported by train.

Systematic field work started in the area north of the Fruska Gora Mountains (north of the Danube at Novi Sad, Serbia). At the 1906 meeting of the Internationale Erdmessung (IAG's forerunner) held in Budapest, Eötvös presented his results. The audience was sceptical about the accuracy of the field observations. Eötvös in response offered a visit to the field party working in the vicinity of the City of Arad which was led by his ex-student Dezső Pekár, by now his highly-respected collaborator. The participants accepted the offer and after the visit, with the impressions they gained, they sent a memorandum to the Hungarian Government proposing that the latter should support Eötvös' work. Up until 

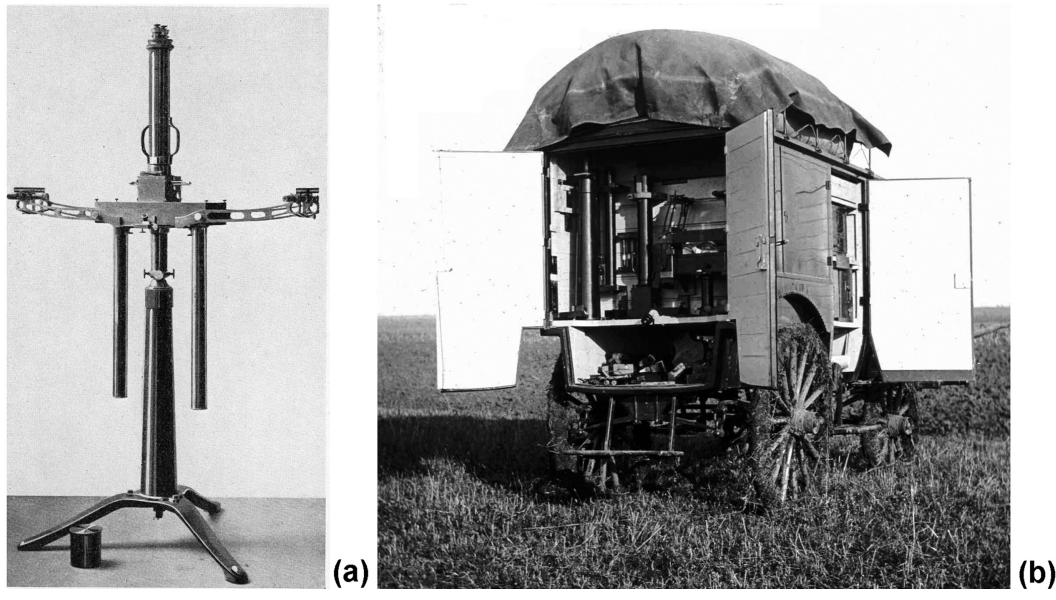

Fig. 8 (a) Large double balance, the final version of the Eötvös torsion balance, (1902), and (b) the cart for transporting the balance in the field

then, he had been financed by a rich landowner, Andor Semsey, a philanthropic supporter of earth sciences. Thanks to this memorandum, from 1907 onwards Eötvös' research was financed by the government. It may be worth mentioning that the field work around Arad produced the first geological section in the world based on gravity measurements (Fig. 9).

At the Internationale Erdmessung meeting in 1912 in Hamburg Eötvös said this about the practical application of the torsion balance (Eötvös 1912): "Geologists seem to agree that the most substantial discharges of gas occur in the immediate vicinity of gas-bearing anticlines and the overlying sediments. Experience gained in America (Ohio) and observations in Transylvania, where the subsurface geological structures could be determined from superficial indications, further endorse these assumptions. Such geological indications, however, are absent in the sand and humus-covered surface of the Great Hungarian Plain. He who searches for gas-bearing anticlines in this or similar areas should not fail to take note of conclusions drawn from torsion balance observations."

To illustrate how important geological interpretation was for Eötvös, the physicist, it is necessary to quote his words of almost poetic beauty from his presidential address to the Hungarian Academy of Sciences given at its 1901 Annual General meeting: Beneath our feet stretches the open country of the Hungarian Plain, crowned with hills. It was gravity which smoothed its surface. I wonder what it was like in former days. What sort of hills have been eroded and what valleys filled with loose deposits before this fertile area of golden grain came into being, this life-giving Hungarian Plain? While I walk upon it and eat its bread my mind dwells upon these questions which would give me such joy to answer.

The first decade of the twentieth century saw the beginning of the detailed geological mapping of the Transylvanian Basin with its main aim of finding potash deposits needed for the manufacture of fertilisers. Initially the distribution of salt-water wells were mapped and their water analysed but with no success. Then, at the suggestion of Lajos Lóczy senior, a well was drilled near the village of Nagysármás in 1908 which similarly yielded nothing significant. A further well however, drilled near Kissármas, found gas which blew out with such a force that the wooden drilling rig caught fire. Soon more wells were drilled (Böhm 1939). 


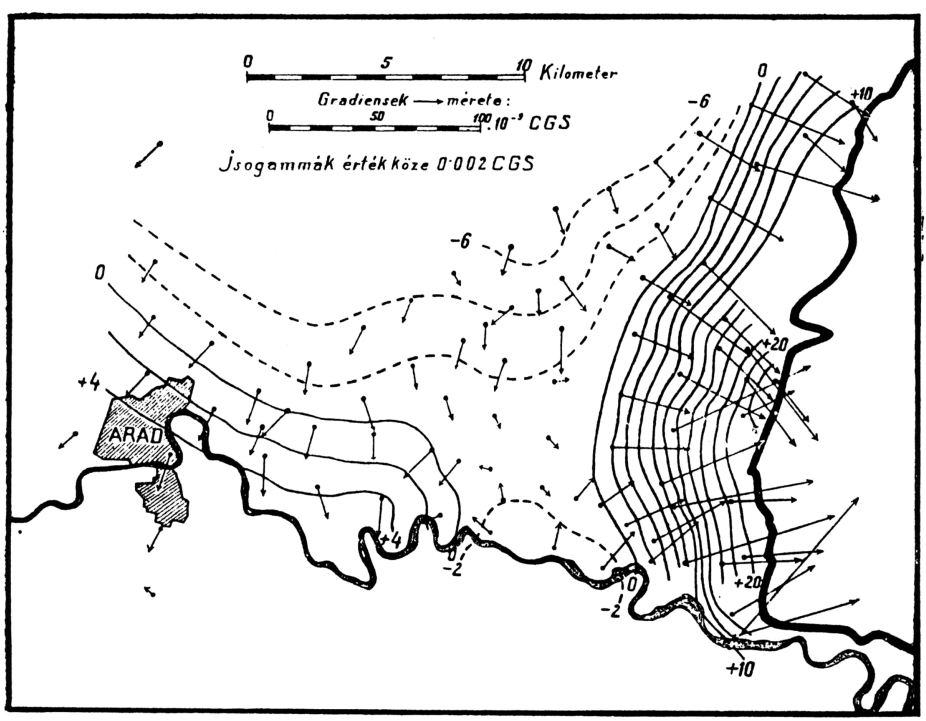

Gradiensek és izogammák Arad vidékén.

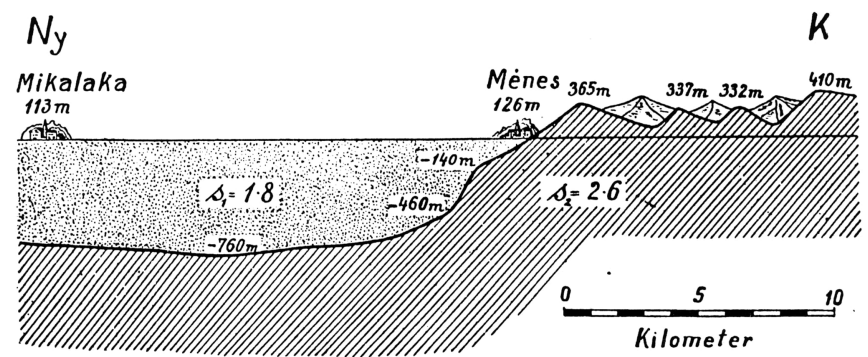

Földalutti levesztmetsuct. "torzirs inguméréscls alnpján. Arad vidékén

Fig. 9 Gradient map and geological section of Arad district from torsion balance data (1906)

In the geological fraternity it was Hugo Böckh, the Head of the Mines Section of the Finance Ministry, who first drew attention to the great practical possibilities offered by Eötvös' torsion balance in the detection of anticlines and salt-domes in hydrocarbon exploration. At his suggestion a ministerial directive was issued and large-scale torsion balance surveys were carried out between 1912 and 1914 in the Transylvanian Basin. Eötvös himself interpreted the results of the surveys and at his suggestion the gravitational maximum in the vicinity of Maroskoppánd was drilled. This was the first occasion in Hungary for a well being sited on the basis of a torsion balance survey.

It was also due to Hugo Böckh's proposal that a test of the usefulness of torsion balance exploration was set up on the oil field in the vicinity of Egbell (now Gbely, Slovakia). The Egbell discovery was said to have been made by a certain János Medlen, a farmer, who had spent some time in America. On his return to his native country he bought some land near 
Egbell and, while ploughing his land he noticed a strange smell which he identified, on the basis of his American experience, as natural gas leaking from the subsoil. His supposition was confirmed when he set the gas alight. Being a practical man he built a 'pipeline' out of bricks to his house and used the gas for cooking and heating. News spread quickly in the neighbourhood and the discovery of free fuel reached the ear of the authorities who immediately reported it to their superiors until finally it reached the relevant ministry. Three geologists, Hugo Böckh, Vazul Lázár and Simon Papp visited the area and mapped out an anticline. This was drilled in 1913 and hydrocarbons were found at remarkably shallow depths; gas between 70-160 m and oil between 160-250 m. Producing wells drilled later contoured the exact extent of the anticline (Böckh 1917).

The Eötvös balance survey started in the summer of 1916. From Pekár's notes we know that observations were carried out at 92 stations. The survey was pronounced as a success because the isogams, computed from the gradients, reflected the exact contours of the productive anticline (Fig. 10). Based on the map Pekár was able to state confidently that: "In the vicinity of Egbell our survey produced exactly the same structure that was identified by the geologists." It is worth citeing the other party too:... "even if we had not had the geological map, the isogamma map would have provided a secure basis for locating a drilling site." wrote Hugó Böckh in his official report, while Simon Papp reflects on these events in his memoir as follows: "I was not allowed to communicate the results of my structural and stratigraphic surveys to the geophysicists until they had finished their own work. Then it became clear that the two different approaches produced almost identical structural results proving, for the first time anywhere, that gravity surveys are suitable for proving the presence of hydrocarbon bearing structures."

Following WW1, the news of the success of the Egbell survey spread rapidly. Many oil companies sent their geologists to the Eötvös Institute in Budapest to acquire the techniques of torsion balance data acquisition, processing and interpretation. By the 1920s the Eötvös Institute had become a virtual Mecca of the oil industry. A significant portion of these visitors later on became leaders in various oil companies or formed their own geophysical companies. Among these was James C. Templeton who, as a geologist with

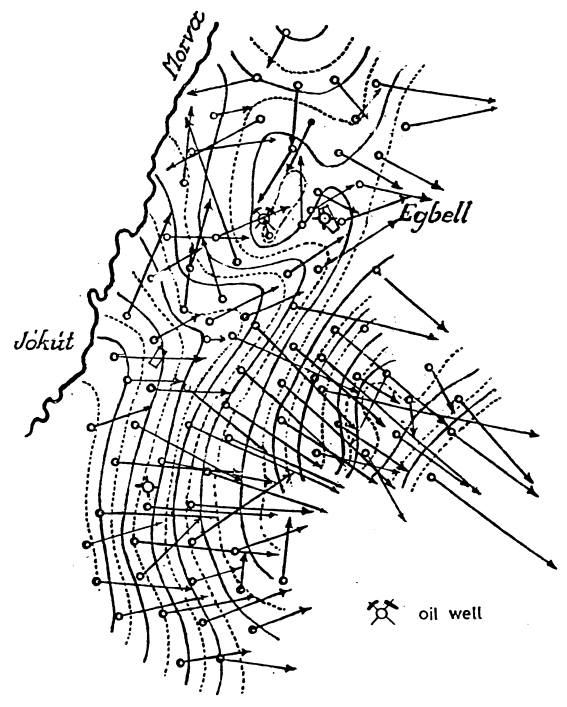

Fig. 10 Gradient map of the Egbell test area, 1916 
the Anglo-Persian Oil Company, spent several months in the Eötvös Institute in 1923. Following his visit he established the International Prospecting Company and later the British Geophysical Agency. Both companies were instrumental in popularising Hungarian-manufactured Eötvös balances in the British Empire. It is thanks to him and many others that interest in Hungarian-made instruments and in Hungarian earth scientists increased abroad. As a result, Hungarian geophysicists worked in the USA, Mexico, Venezuela, Chile, France, India, Persia etc.

Eötvös did not live to see the great success of the torsion balance in the oil exploration industry but his scientific achievements were written into the annals of physics and geophysics.

\section{The First Golden Age}

The first use of the Eötvös balance abroad dates back to 1917. Schweydar (1918) who, following Hugo Böckh's Egbell publication, carried out a successful test survey in the area of Nienhagen-Haeningen (North Germany) over a partly known salt diapir (Fig. 11). In hydrocarbon exploration the first pioneers outside Hungary were the Royal Dutch Shell Company and the Anglo-Iranian group (De Golyer 1938). As far as we know, the first actual survey was over the Hurghada field (Egypt) either during the autumn of 1921 or spring 1922. In the USA, De Golyer ordered the first torsion balances from the Süss Company in Budapest (Proubasta 1984). The first two instruments arrived in November 1922 and these were the first geophysical instruments used in hydrocarbon exploration on the American continent.

Gilmour gives a colourful account of his first acquaintance with the torsion balance. His degree was in physics and he was specially employed to work with the Eötvös balance. As

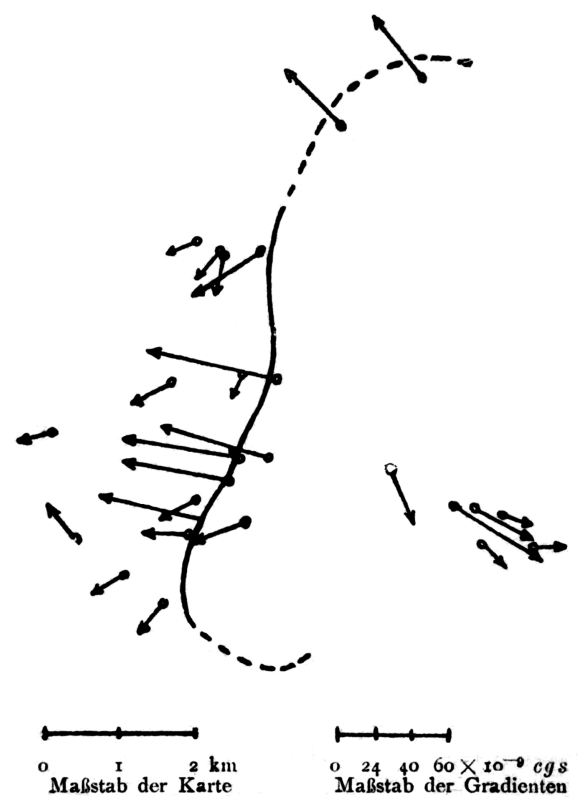

Fig. 11 The result of Schweydar's first test survey in North Germany (1917) 
he started his job before the first balances had arrived, his boss, Donald Barton, asked him to translate Eötvös' paper which was published in German (Eötvös 1909). Gilmour's only foreign language was French (beside schoolboy Latin and Greek) so with the help of a German dictionary and grammar he started the almost hopeless task. When he completed the English translation he proudly presented the work to Barton but it turned out that he had already translated it and had only given the job to Gilmour so that he had something to do while waiting for the instrument to arrive.

The first torsion balance survey was done by Gilmour under Barton's supervision over the Spindletop (Texas) field which is associated with a salt diapir (Barton 1928). This is the first example of mapping by geophysical methods over a known oil field in the American continent and it followed the Egbell example, although the trap in this case was over a salt dome and not an anticline. The first actual oil field discovered by torsion balance survey was the Nash Dome (Brazona County, Texas) (Fig. 12). These first successes were quickly followed by others. According to Jakosky (1940) at the beginning of the 1930s more than 125 torsion balances were in use in the USA and by 1938 on the Gulf Coast alone some 79 discoveries were made by torsion balance surveys.

The spread of application of torsion balance surveys on the American continent was due to a large extent to Jenő Fekete, a student and later assistant of Eötvös, who between 1923 and 1926 worked for the Royal Dutch Shell Company in Mexico and Venezuela on torsion balance surveys. From 1934 to 1937 he was employed by the Torsion Balance Exploration Co. in Louisiana and Texas as a geophysical consultant. During his work abroad he was associated with more than 80 exploration projects. After his return to Hungary he replaced the now retired Dezső Pekár as Director of Eötvös Loránd Geophysical Institute (ELGI). His foreign experiences were put to good use as he introduced up-to-date geophysical methods (seismic, electric, well logging etc.) into Hungary during his directorship.

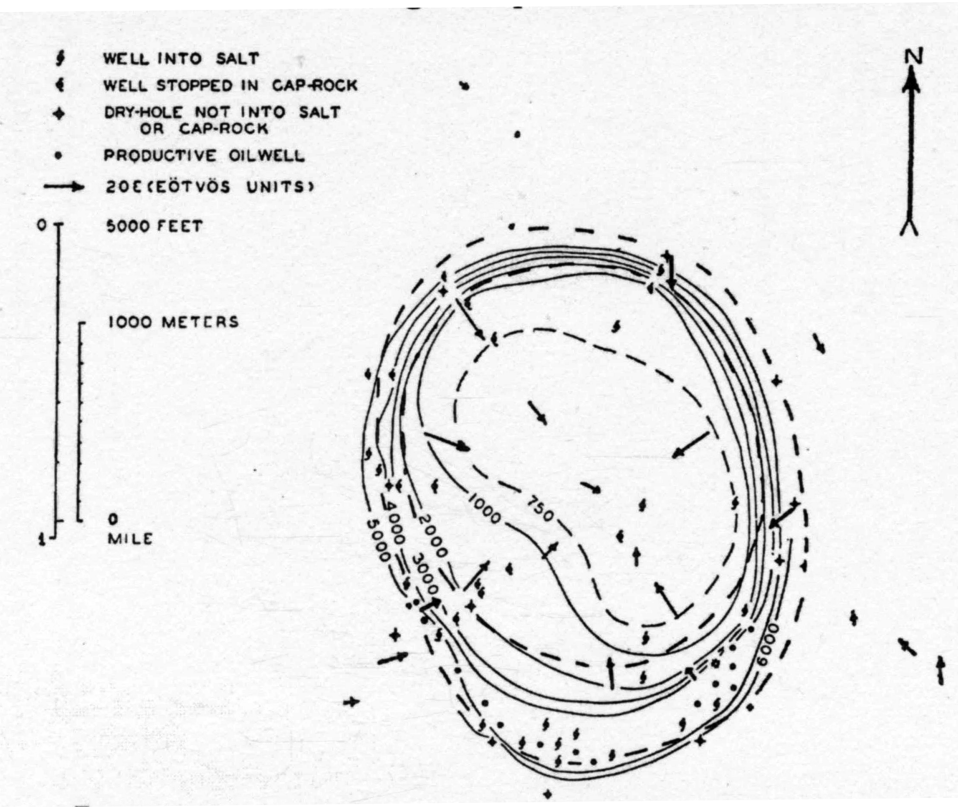

Fig. 12 The first oil field discovery by torsion balance survey in the USA (1924) 
While during Eötvös' lifetime torsion balances were built one by one, after his death the demand for the instrument from oil companies grew to such an extent that the now joint stock Ferdinand Süss Company had to introduce the serial production of the Large double balances in 1922. The modifications applied to the original model were as follows: the instrument housing was now made of aluminium instead of brass to cut down weight, the two platinum masses were replaced by gold and the upper, originally cylindrical mass, was changed to a more flat shape to facilitate better air damping. The arresting mechanism was modified so that the instrument could be transported in any position. All these changes made the instruments much more user-friendly. What remained unchanged was the "soul of the instrument", the torsion wire. Its preparation, the determination of its coefficients (torsion, thermal, elastic) and the instruments' constants were done in ELGI's laboratories, as well as the final quality control.

Parallel with the development of series production, the ex-students of the master continued perfecting the instrument. Two divergent trends developed. Dezső Pekár's starting point was Eötvös' last, 1908 version, the Small Double Balance (Fig. 13a) which, due to its smaller weight and dimensions, was effected by the interference of wind, ground noise etc. significantly. (It is worth mentioning that in the same year a water-cooled version was also developed, enabling observation during the day but as cooling water was not always available, this somewhat reduced its usefulness). Pekár, with long experience in operating the instrument in the field, believed in the preservation of simplicity of the equipment and argued for the retention of manual rotation and visual reading. The undoubted advantage of this method is that the observer can continue to observe until the best possible reading is

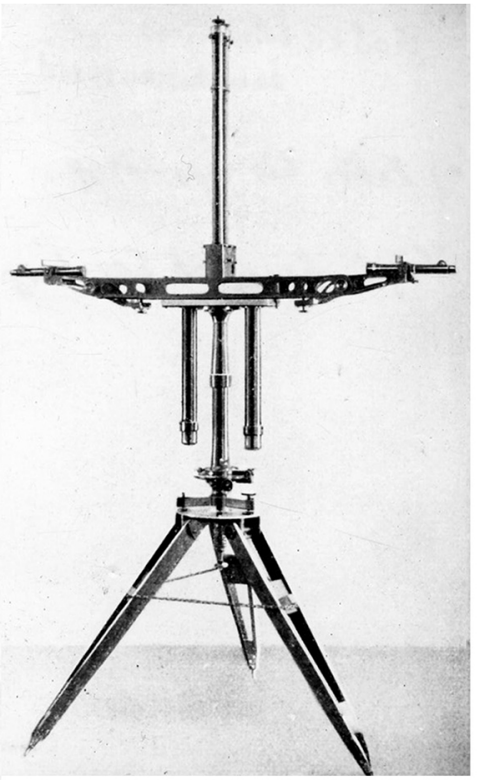

(a)

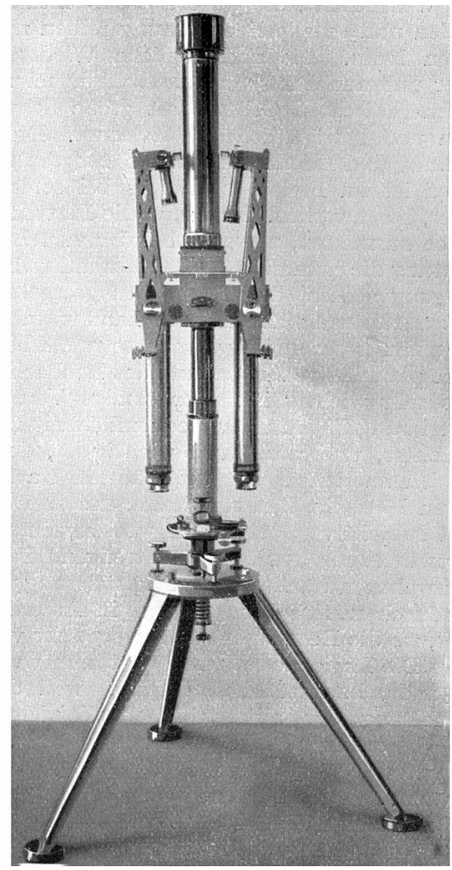

(b)

Fig. 13 Eötvös' Small double balance, 1908 (a), and its improved modernized version, Pekár's Small Original Eötvös Balance, 1927 (b) 
obtained in contrast to the more uncertain outcomes when using equipment with photographic recording where errors are not realised until the photographic plates are developed. The disadvantage is the need for the constant presence of the observer. Pekár's torsion balance was designated as the Small Original Eötvös G-2 (Fig. 13b). This instrument had three variants; they differed from each other in the length of the torsion wires only. The model which was first manufactured in 1926 had a $50 \mathrm{~cm}$ long wire, the one in 1928, $40 \mathrm{~cm}$, while the 1930 model had a $30 \mathrm{~cm}$ wire (Pekár 1941).

István Rybár, Eötvös' successor at the University of Budapest from 1940, was working on the reduction of the dimensions and the automation of data recording. By the midtwenties he developed his Auterbal (Automatic Eötvös-Rybar Balance) type GR5 (Fig. 14a) which had a 40 min recording period, and the rotation of the instrument was done by a clock mechanism and data reading was photographically recorded. The automation made the constant presence of the observer unnecessary and thus he was able to operate two balances simultaneously. One must admit, however, that the delicate clock mechanism needed constant attention (Rybár 1929).

The discovery of the first significant oil field in Hungary at Budafapuszta is also connected to the torsion balance. Geological mapping had been ongoing in the area for some time by the Hungarian Oil Syndicate-a subsidiary of the Anglo-Persian Oil Co. Based on the geological mapping by Ferenc Pávai-Vajna, Hugó Böckh sited a well which was drilled to a depth of $1737 \mathrm{~m}$ but found only traces of oil and gas. In 1934 EUROGASCO obtained a concession covering a large part of Transdanubia (W Hungary) and initiated a regional torsion balance survey. In spite of the difficult, hilly terrain, the survey indicated a positive anomaly axis which was just $1500 \mathrm{~m}$ north of the 1920 dry hole (Fig. 14b). In the meantime the concession became the property of MAORT (Hungarian-American Oil Co.) a subsidiary of Standard Oil. The Budafapuszta No. 2 well was located on the axis of the structure and on 21st November 1937 oil was discovered. This date marks the birth of the

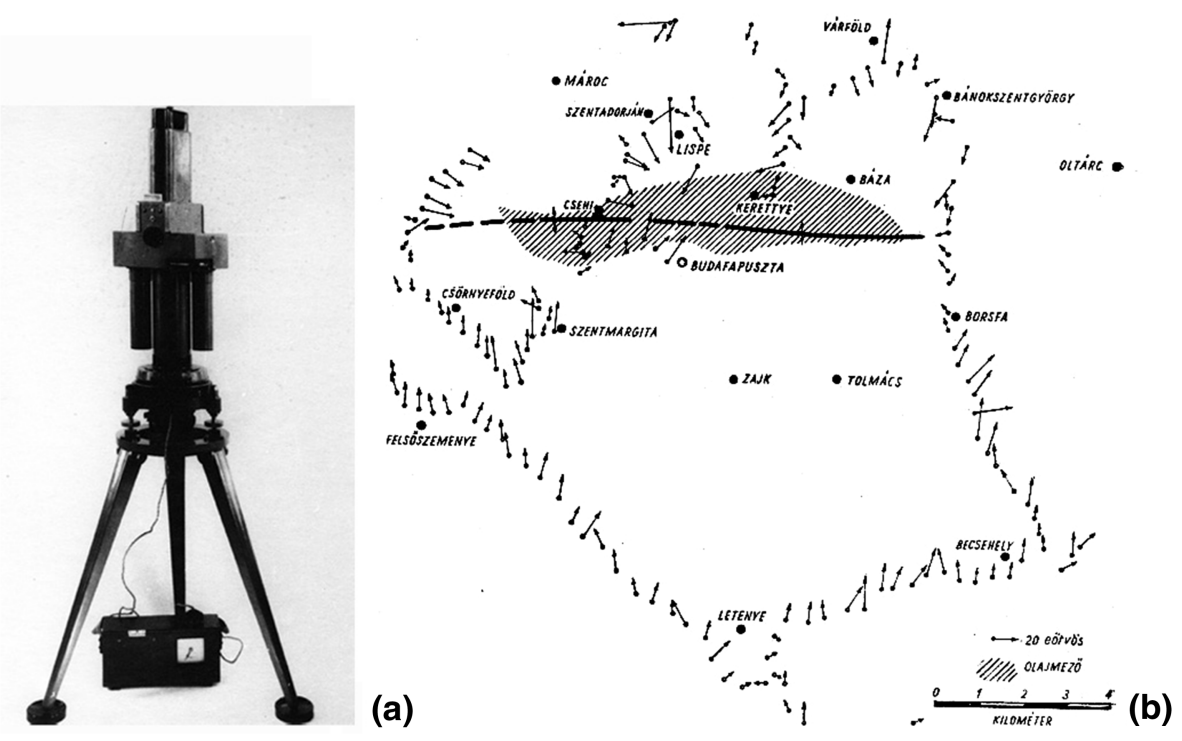

Fig. 14 (a) Automatic Eötvös-Rybár Balance (Auterbal), 1928, used in the Budafapuszta (SW Hungary) torsion balance survey (b), resulting in the discovery of the first oil field of Hungary in 1937 
Hungarian oil industry (Papp 1939). As an interesting aside it is worth mentioning that according to the reminiscences of Pávai-Vajna the original location of the 1920 well was planned further north but the Englishman in charge of the rig refused to locate it on a hill. Si non e vero e ben trovato.

By the end of the 1930s the smaller and more easy-to-handle gravimeters, although are less "intelligent" and of lower sensitivity than torsion balances, were more productive and gradually took over the role of the latter in hydrocarbon exploration.

\section{The Second Golden Age}

After WW2 the embargo on "strategic sales" to the socialist states made it impossible for the Eastern bloc to purchase modern gravimeters. This gave the impetus in 1952 for the development by ELGI of a modern version of the torsion balance to satisfy demand within the area. The task was given to István Rybár and Gyula Banai. Rybár had decades of experience in designing instruments while Banai had over two decades of operating experience. The new instrument had the following design requirements:

- High sensitivity: 2.5-3.0 E/scale division,

- Totally automatic operation,

- Shortest possible observation period,

- Negligible thermal effects.

The designers' starting point was the Eötvös-Pekár instrument's beam dimensions and the Auterbal balance's automatic recording system. Banai's extensive experience in field work made him well aware of the weak points of the automatic and photographic system therefore he tried to design a more reliable instrument. The prototype of the new torsion balance was ready by the end of 1954, made by the precision engineering workshop of ELGI and it was therefore designated as type E-54 (Fig. 15). The simultaneous recording on photographic plates of the crosshair and the scale simplified data processing to a great extent. The photo plate also recorded the factory serial number of the particular instrument and, by an adjustable mechanism, the station number as well. This further helped data processing by preventing the accidental mix-up of plates. The recording period of the instrument was $40 \mathrm{~min}$. The serial manufacturing was carried out by a cooperative of the old Süss factory's staff in traditional cooperation with ELGI (Rybár 1957).

Between 1956 and 1960 altogether 109 balances were produced and, except two, all exported. This instrument received the Grand Prix of the 1958 Brussels World Expo. From 1959 , attempts were made to reduce the length of observation period even if this led to a reduction in sensitivity. By 1960 these attempts were successful and the type E-60 was born which differed from the previous model only by its wire and damping. Between 1961 and 196573 type E-60 were made of which 70 were exported. Considering that more instruments of these two models were manufactured than all the pre-war types altogether, we are justified in calling this period the 'Second Golden Age' of the Eötvös torsion balance.

One outcome of the resurgence of torsion balance production was the setting up of the Chinese-Hungarian Geophysical Expedition in 1956. Within the framework of this project, Hungarian geophysicists and geologists carried out hydrocarbon exploration in the People's Republic of China for several years. Another task of the expedition was the training 


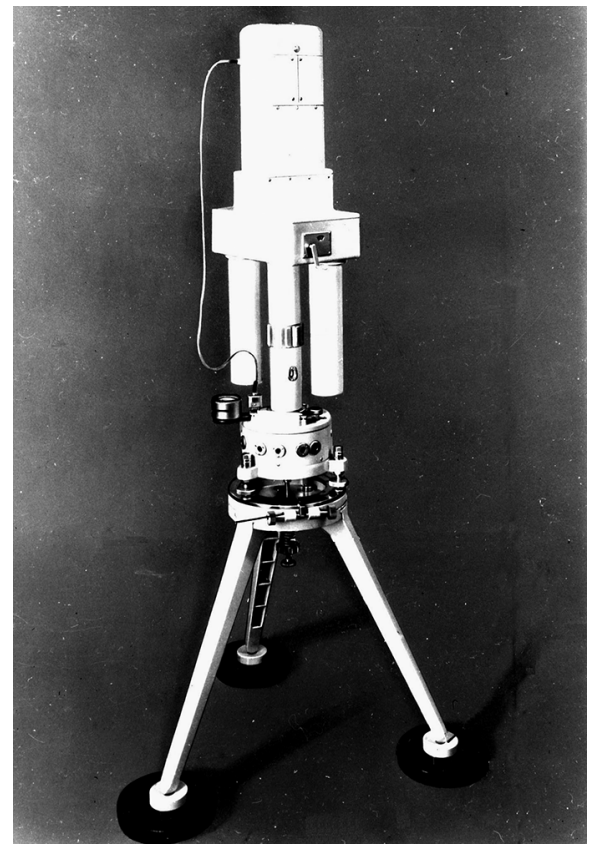

Fig. 15 The last generation torsion balance: type E-54, 1954

of significant number of Chinese geophysicists-some of whom are in executive positions today - and remember the activities of the expedition with appreciation.

Parallel with the manufacture of the type E-54, the Geophysical Instrument Factory, under the leadership of Miklós Szecsődy-a one-time collaborator of Eötvös—started to develop a 15 min recording-period visual instrument which later was complemented by photographic recording. The prototype was designated as Eötvös-Szecsödy type Y-59. The moving part of the balance differed from the traditional in as much as the arm of the pendulum was no longer horizontal but was inclined at $45^{\circ}$. Hence the $\mathrm{Y}$ in the designation. Experience gained from the type E-54 was incorporated into the new instrument resulting in the reduction of observation period and weight.

The low weight of the new instrument was a definite advantage and its sensitivity and accuracy approached that of type-54 but the manually controlled damping device made the operation too complicated and needed the constant presence of the observer. In spite of some of the undoubted advantages offered by the instrument it could not compete with type $E-54$ which was already in production and thus it never got off the ground.

In the 60s attempts were made to develop a gradiometer with about 10 min recording period and four beams. A prototype was made but due to lack of demand the project was cancelled. In 1969 ELGI's torsion balance laboratory was closed and the history of torsion balance development and manufacturing in Hungary came to an end.

The last torsion balance field work was carried out in 1966. During the period 1901-1966 a total of 60,000 Eötvös balance stations were established in Hungary. This number includes about 5000 beyond the present borders of the country.

The original instruments are permanently exhibited in the memorial museum, set up in the office building of MFGI which is open to visitors. 


\section{The Eötvös torsion balance abroad}

The history of Eötvös' torsion balance would not be complete if we did not deal with the efforts of foreign scientists to copy his instrument. When Eötvös built his first instrument he was lead by scientific considerations and did not recognise its possible economic significance and did not patent it. As a result, even during his life-time, several attempts were made, with varying degrees of success, to copy his torsion balance. Eötvös dealt with all enquiries in the most friendly and helpful way (Pekár 1925). The first interest from outside Hungary came from Germany in the person of Professor O. Hecker, who in the Potsdam Geodetic Institute, and with the help of M. Fechner, built a double torsion balance based on Eötvös's model. Writing about his work to Eötvös he said: "I am not satisfied with the suspending wires and I wonder if it would be very presumptuous of me to ask you to send me two, or even better, four torsion wires. I would be extremely grateful". Apart from sending Hecker everything he requested, he also provided all the technical information about the instrument. It was on the basis of this report that W. Schweydar constructed a new type of torsion balance with photographic data recording. Later this model formed the starting point of the instrument family produced by the Askania Company in Berlin which became the main competitor for the Hungarian Süss company's instruments.

The first of the series, the so called "large" balance (L-40), kept the shape of the Eötvös-type beam and in all respects resembled Eötvös' "large double balance" (Fig. 16a). Later Schweydar built a balance with a Z-shaped torsion beam (model Z-40, Fig. 16b). In the following years this model proved to be the most successful of the Askania instruments and provided the greatest competition to the Hungarian-built instruments made by the Süss works. The third variety (model S-20, Fig. 16c) had inclined beams (Askania 1935). The reading period was reduced to $20 \mathrm{~min}$ but in practice the instrument never achieved the
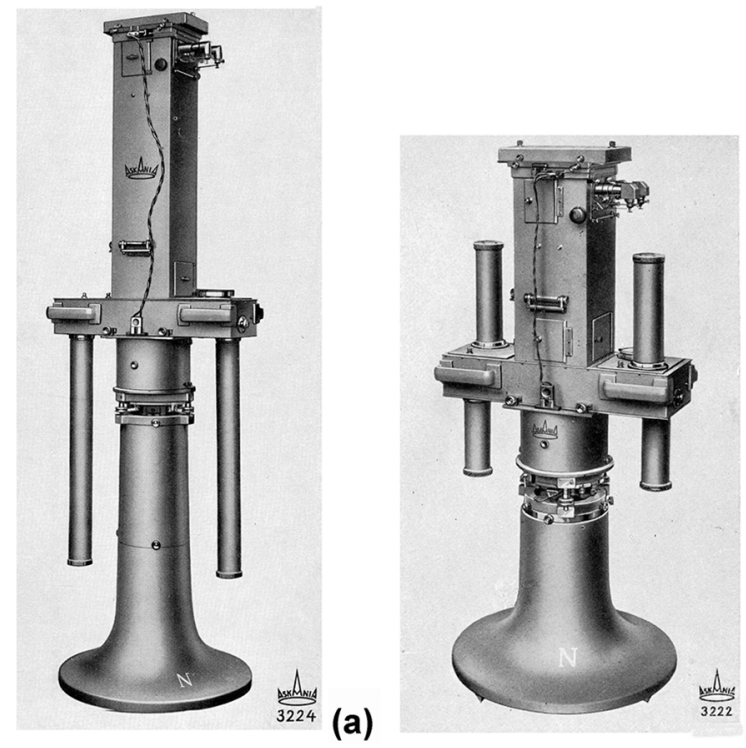

(b)

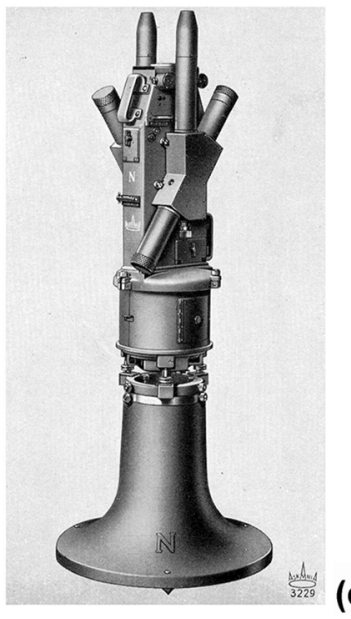

(c)

Fig. 16 Three types of torsion balances developed and produced by the German Askania-Gewerke A.G.: (a) Photographic recording torsion balance type $\mathrm{L}-40$, (b) Z-beam torsion balance type Z-40, and (c) with inclined beams type $\mathrm{S}-20$ 
popularity of the Z-40 type. A comparison of the different types of torsion balances was carried out in the course of a torsion balance survey in India (Fig. 17).

Due to the fact that the first series of torsion balances with photographic recording were brought to the market by Askania, the general belief is that photographic recording was Schweydar's innovation, particularly as he patented the design. As a matter of fact Eötvös had already used the photographic technique for registering the movement of the beam in laboratory experiments and he presented the results at the World Exhibition in Paris in 1900. At the same time he found this technique complicated and difficult to use in the field and in later surveys he discontinued using it. There is no doubt that Schweydar's photographic system, which instead of continuous registration only recorded the instrument's equilibrium positions, proved to be much the simpler.

Another attempt at building torsion balances in Germany is tied to the name of $\mathrm{J}$. Königsberger who was professor at Freiburg and had earlier studied the methodology of torsion balance surveys in Hungary. At his request, Eötvös lent him his 'small double balance' with which, in association with $\mathrm{O}$. Hecker, they carried out field surveys in Germany for several years. Based on this model Hecker developed a new instrument for the Freiburg firm Gesellschaft für Practische Geophysik, the forerunner of a minor series. The London firm Oertling chose the original Eötvös model as the basis of their torsion balance with the main emphasis on a clever automatic recording of data. The instrument, however, turned out to be not suitable for day-time work.

The main effort in refining the instrument further, both abroad and in Hungary, was focussed on reducing the time needed for observation, and various methods were tried. Jung (1961) describes that Halck for instance used two beams at right angles to each other while Hecker designed an instrument with four beams where 2 pairs of torsion beams in antiparallel position, at a $60^{\circ}$ angle with each other. With this instrument it was possible to determine both the value of gradient and curvature in two azimuths. However, the balance never got to the production stage. Kilchling designed a rotating balance with a

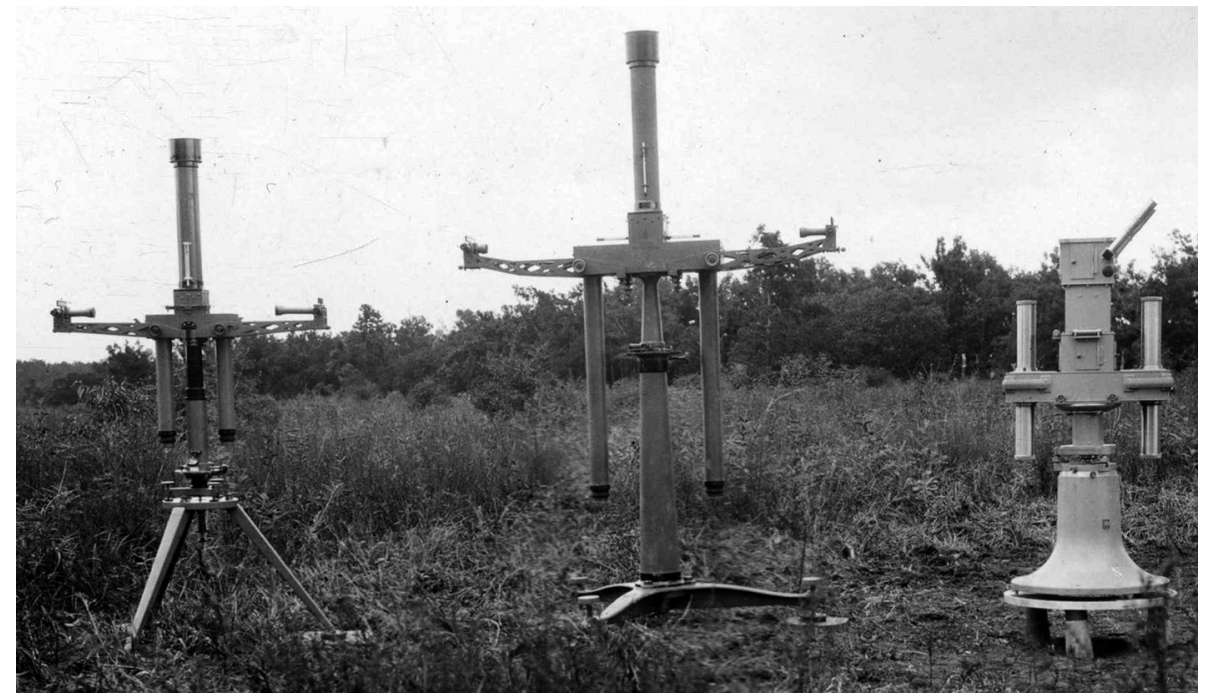

Fig. 17 Comparision of different torsion balances in India, 1927 (from left to right): Small Original Eötvös Balance (G-2), serial produced Large Double Balance, and Askania's Z-beam torsion balance type Z-40 


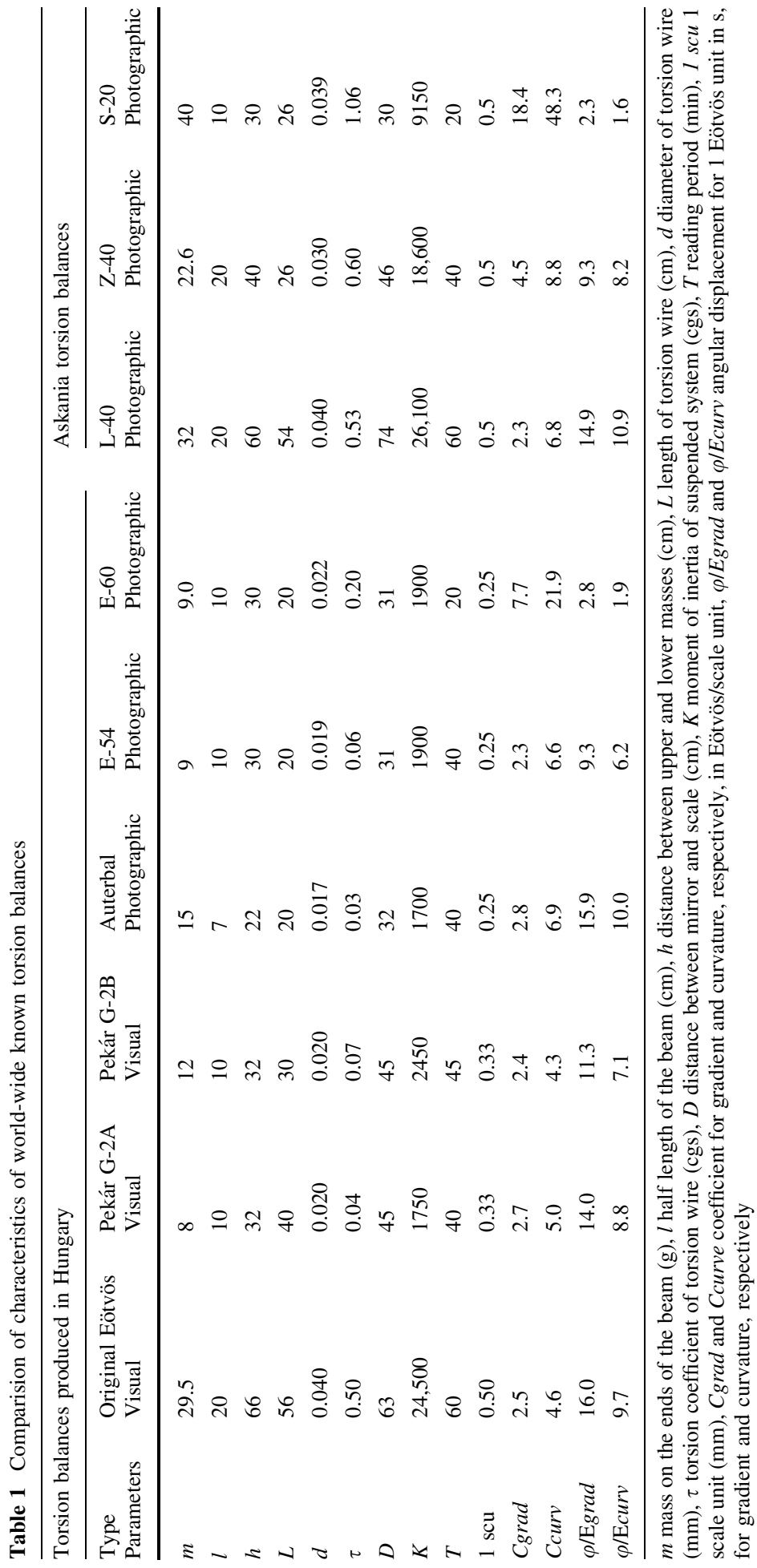


continuously recording photographic system. The damping period of the instrument was $40 \mathrm{~min}$ while one cycle of rotation was $2 \mathrm{~h}$. The continuously recorded data allowed the computation of the components of gradient and curvature. In practice, however, it was found that in spite of the sophistication of the instrument it was no better than the traditional instruments. Tsuboi constructed a small instrument with a quartz beam but, unfortunately, it was not a success. Others experimented with balances which determined the gradients only. The instrument, developed by Shaw and Lancaster-Jones used three torsion beams at $120^{\circ}$ positions, but one torsion beam was in a higher position than the other two.

In Russia, even in Eötvös' time, there was keen interest in torsion balance surveys. Eötvös' papers were translated and enquiries were made to purchase an instrument. The outbreak of World War 1 however, interrupted any further contacts. In the Soviet Union, Nikiforov and Numerov were engaged in constructing torsion balances, but their instruments remained unknown outside the Soviet Union. In more recent times the Geologorazvedka firm in Leningrad developed a four-beam instrument, model GRBM-2, which became well known in the Soviet Union but not elsewhere. Although not a lot is known about the success of this instrument, we assume that it proved unsatisfactory as in the 1950s the Soviet Union bought up the majority of Hungarian-produced torsion balances (Mudrecovoj 1981).

Reviewing the history of development of torsion balances we must come to the conclusion that in spite of many attempts only the Askania torsion balances proved to be the sole competitors of the Hungarian-made instruments. To sum up, Table 1 summarizes the best-known torsion balances which were produced in significant numbers, and their physical parameters (Table 1).

\section{Closing remark}

This article deals with the role of the torsion balance in earth sciences and in exploration for economic resources. Eötvös' torsion balance has also played a key role in physics, namely in the high-precision determination of the ratio of inertial and gravitational mass (Szabó 1998). This, however, should be discussed in a separate paper.

\section{References}

Askania Drehwagen für die geophysikalischen Lagerstätten-forschung (1935) (technical publication). Askania-Werke A. G., Berlin-Friedenau

Barton DC (1928) The Eötvös torsion balance method of mapping geologic structure. Technical Publication No. 50. A.I.M.E., Washington DC

Böckh H (1917) Der Nachweis von Antiklinalen und Domen mittels der Drehwaage. Petroleum XII, pp 817-823

Böhm F (1939) Ásványolaj- és földgázbányászat Magyarországon 1935-ig (in Hungarian). Bányászati és Kohászati Lapok LXXII(9):153-189

De Golyer E (1938) Historical notes on the development of the technic of prospecting for petroleum. The science of petroleum, vol I. Oxford University Press, Oxford, pp 268-275

Egyed L (1969) Physik der festen Erde. Akadémiai Kiadó, Budapest

Eötvös L (1896) Untersuchungen über Gravitation und Erdmagnetismus, vol 59. Annalen der Physik und Chemie, Neue Folge, Berlin, pp 354-400

Eötvös L (1908) Die Niveauflächen und die gradienten der Schwerkraft am Balatonsee; Resultate der Wissentschaftlichen Erforschung des Balatonsees, Band I. Teil I. Geophysischer Anhang II, Budapest, pp 1-64 
Eötvös L (1909) Über geodätischen Arbeiten in Ungarn, besonders über Beobachtungen mit der Drehwage. Hornyánszky nyomda, Budapest

Eötvös L (1912) Bericht über Arbeiten mit der Drehwaage, ausgeführt in Auftrage der königlich ungarischen Regierung in den Jahren 1909-1911. Verhandlungen der XVII. Allgemeinen Konferenz der Internationalen Erdmessung in Hamburg im Jahre, Berlin, pp 427-438

Fröhlich I (1930) Báró Eötvös Loránd emlékkönyv (in Hungarian). Magyar Vendeglo, Budapest

Jakosky II (1940) Exploration geophysics. Trija Publishing Co., Los Angeles

Jung K (1961) Schwerkraftverfahren in der angewandten Geophysik. Akademische Verlaggesellschaft, Leipzig

Mudrecovoj EA (1981) Gravirazvedka. Nedra, Moskva

Papp S (1939) A Magyar Amerikai Olajipari Részvénytársaság földiolaj- és földigázkutatásai a Dunántúlon (in Hungarian). Bányászati és Kohászati Lapok LXXII(9):203-241

Pekár D (1925) Die Entwicklung, Empfindlichkeit und Verlässlichkeit der Eötvösschen Original-Drehwagen. Zeitschrift für Instrumentkunde 45(10):486-493

Pekár D (1941) Báró Eötvös Loránd. A torziós inga 50 éves jubileumára (in Hungarian). Kis Akadémia, Budapest

Proubasta D (1984) Remembrance of geophysical things past. Geophys Lead Edge Explor 3(10):32-38

Rybár I (1929) Új szerkezetü Eötvös-féle torziós inga (in Hungarian). Mathematikai és Természettudományi Értesítő 46:698-722

Rybár I (1957) Eötvös Torsion Balance Model E-54. Geofisica Pura e Applicata 37:79-89

Schweydar W (1918) Die Bedeutung der Drehwaage von Eötvös für die geologische Forschung nebst Mitteilung der Ergebnisse einiger Messungen. Zeitschrift für praktische Geologie 26:157-162

Szabó Z (ed) (1998) Three fundamental papers of Loránd Eötvös. Eötvös Loránd Geophysical Institute of Hungary, Budapest 